\title{
Mediating ethnic conflict at the grassroots: the role of local associational life in shaping political values in Côte d'lvoire and Ghana
}

Lauren Morris MacLean*

\author{
A B S T R A C T
}

This article attempts to understand why ethnic-regional civil war has challenged the national unity of Côte d'Ivoire and not Ghana, two neighbouring countries with nearly identical ethnic, religious and regional divisions, by examining politics at the grassroots. Based on a carefully controlled comparison of two similar regions of Côte d'Ivoire and Ghana, the study investigates how participation in local voluntary associations reinforces the local experience of the state to shape the ongoing development of political values and affect the prospects for ethnic peace and democracy. The article finds that participation in ethnically heterogeneous voluntary associations does not necessarily promote democratic values and practice. In fact, in Côte d'Ivoire, participation in ethnically heterogeneous cocoa producer and mutual assistance organisations reinforces vertical patronage networks based on narrower ethnic identities. In contrast, in Ghana, participation in more ethnically homogeneous local church groups encourages the development of democratic values and practices at the local level that mediate the potential for ethnic conflict and support the consolidation of a democratic regime.

\section{INTRODUCTION}

While political instability and ethnic strife are hardly new in Africa, recent events in Côte d'Ivoire, a country that for decades has been heralded as a haven of political stability and economic growth on the continent, have startled and troubled many academics and policymakers. What began as a

* Assistant Professor, Department of Political Science, Indiana University

The author gratefully acknowledges the support of the Robert Wood Johnson Foundation, a Fulbright-Hays Doctoral Dissertation Research Abroad fellowship and grants from the Social Science Research Council, Institute for the Study of World Politics, and the University of California-Berkeley's African Studies Center.

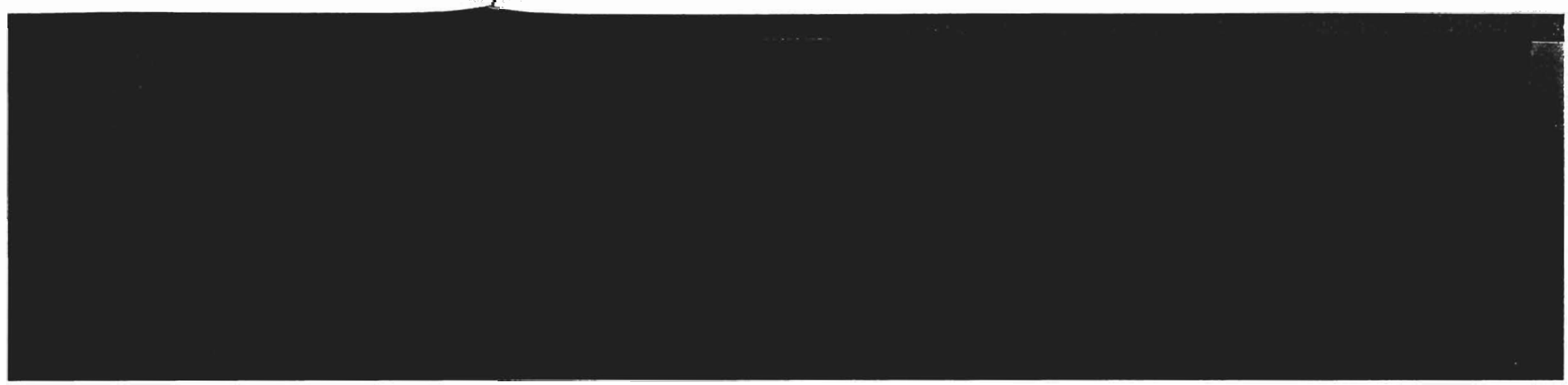


surprising series of coups d'état in Abidjan in November 1999 grew into a protracted struggle between rival ethnic-regional factions for power, finally exploding in September 2002 into a full-scale civil war that menaced the unity of the country. While a ceasefire was officially declared in May 2003 , the disarmament of an estimated 25,000 to 30,000 combatants has yet to begin, and ethnic clashes continue, particularly in what is now known as the 'Wild West'.

Meanwhile, neighbouring Ghana, which is characterised by nearly identical ethnic, religious and regional splits and moved to a multiparty system during the same period, ${ }^{1}$ has continued to consolidate its nascent democracy (Gyimah-Boadi 2001; Smith 2002). In contrast to the rebellion and bloodshed in Côte d'Ivoire, the transfer of power to an opposition party in Ghana for the first time in nearly 20 years occurred with only a few isolated incidents of violence in the 2000 elections. While ethnic conflict has flared recently in several regions of Ghana, to date the conflicts have been relatively localised and have not been motivated by ethnic or regional claims to national power as in Côte d'Ivoire. ${ }^{2}$

What explains the differences in the ways that ethnic conflict erupts and plays out in the two countries? Why have similar ethnic cleavages become national battle lines in Côte d'Ivoire, but only comparatively sporadic, local boundary disputes in Ghana? In order to understand how ethnic conflict may be mobilised or mediated in national politics, we must first examine how the potential for conflict is managed at the local level, the focus of this analysis. While much of the literature on ethnic conflict focuses on international or national-level politics during a particular crisis period (Brown 200I; Deng \& Zartman 1991; Lake \& Rothchild 1998; Rothchild I997; Stedman et al. 2002), this study examines everyday politics at the grassroots during 'normal' times. In particular, the article investigates how participation in different types of local associations combines with contrasting legacies of state-society relations to shape different sets of political values and practices at the local level. Based on a carefully controlled comparison of two neighbouring regions of Côte d'Ivoire and Ghana, the findings demonstrate that participation in ethnically heterogeneous associations does not necessarily promote cross-cutting social capital and cooperation in Côte d'Ivoire, as Varshney's (2002) work in India might suggest, but rather reinforces ethnically based vertical patronage networks between the village and capital. In contrast, participation in ethnically homogeneous church groups encourages the development of democratic values and practices at the local level in Ghana.

These differences in grassroots civil society and politics are not the only factor explaining the outbreak of ethnic conflict in Côte d'Ivoire and relative peace in Ghana. ${ }^{3}$ Rather, this type of empirically grounded, locallevel analysis is a necessary first step in understanding the dynamics of the broader national context. While there are unquestionably other important national and international causes precipitating violence in Côte d'Ivoire, this study seeks to illuminate how grassroots politics can either work for or against potential ethnic conflict.

THE MISSING LINKS BETWEEN ETHNIC CONFLICT, CIVIL SOCIETY, SOGIAL GAPITAL AND.DEMOGRATIC GONSOLIDATION

While the study of civil society, social capital and democracy are frequently connected and even made conceptually interdependent, ${ }^{4}$ the literature on ethnic politics remains largely a separate and autonomous field of inquiry. In order to enhance our understanding of the process of democratic consolidation in ethnically divided societies in Africa and elsewhere (Ayee 200I; Bratton \& van de Walle 1997; Diamond 1999; Gyimah-Boadi I999; Linz \& Stepan I996; Schmitter 1992, I994), we need to link insights from the ethnic politics literature to the civil society and social capital literatures. The work of Ashutosh Varshney (2002) is a noteworthy exception in its efforts to connect these disparate literatures. While sharing similar objectives, Varshney's conclusions differ in important ways from this study. While also emphasising the preventive role of civic networks in mitigating communal violence, Varshney highlights the heterogeneity of associational membership in stimulating cross-cutting social ties across Hindu and Muslim communities. In contrast, this research reveals that a heterogeneous membership does not guarantee a growth in cross-group understanding or cooperation; instead, it is the parameters of participation encouraged within the association and corresponding community political institutions that matter most critically. Essentially, while Varshney emphasises the interaction of different identities, this study problematises the nature of the interaction itself.

First, the literature on ethnic politics is expanded by focusing on the grassroots level during periods of 'normal' politics. Much of this literature has either remained at the level of individual identity and psychology (Barth 1969; Geertz 1973), or concentrated on the level of the nation to evaluate what factors (e.g. institutions, structures, and/or cultural histories) exacerbate or mediate ethnic conflict (Rothchild 1997; Stedman et al. 2002). Furthermore, much of the literature has focused on the resolution of ethnic conflict, selecting cases where ethnic strife has already become highly visible, politicised, and costly (Longman I999; Stedman et al. 2002). Not enough attention has been devoted to non-crisis periods at the 
community level to understand how local-level institutions may shape individual values and identities, mediate conflict at the grassroots, and support national cohesion, preventing widespread ethnic conflict in the first place. $^{5}$

Second, in addition to refocusing the analytic lens on ethnic politics, the article also contributes to the evolving literature on civil society by looking extensively within civil society organisations. Rather than assuming a connection between civil society and democracy (or between civil society and the perpetuation of societal inequality as the dissenters would argue), the internal structure and functioning of civil society organisations is critically examined to ask how participation in different types of organisation may influence the development of political values and practices at the local level. ${ }^{6}$ Supporting VonDoepp's (2002) analysis of local church groups in Malawi, the study finds that the inner politics of the organisations are more tightly connected to the actual opportunities for political participation and empowerment than may be anticipated by such general organisational descriptors as decentralised or hierarchical organisations. ${ }^{7}$

Another key insight emerging from this cross-national comparison is that the organisation and experience of participating in civil society cannot be separated from the different legacies of state-society relations in a particular area. It is not only essential to examine how civil society is structured by the balance of societal power, as VonDoepp does so well with regard to gender inequalities, but also by the divergent experiences of the state. Contrasting histories of state-society relations in Côte d'Ivoire and Ghana (Boone 1995, 2003; Crook 1991; Crook \& Manor 1998; Fauré 1993; Nugent 1995; Owusu 1970; Widner 1993; Woods 1994, 1999) shape the ways in which individuals even conceive of organising civil society at the local level. Then, experiences within civil society organisations often parallel and thus reinforce the initial variation in the ways that individuals interact with the state. ${ }^{8}$ Thus, differences in the organisation of civil society are not the only reason political values and practices differ at the grassroots. However, this is an important factor which has not been adequately considered, particularly in relation to the mediation of ethnic conflict.

Third, several of the criticisms of the social capital literature are addressed. Much of this literature suggests that participation in local voluntary associations fosters social capital that increases economic development (Fukuyama 1995), enhances good governance (Ostrom 1990; Putnam 1993), and bolsters the prospects for democracy (Putnam I993). Not only is the development of social capital taken for granted, and essentially assumed to be 'positive', ${ }^{9}$ the mechanisms between participation in local associations and actual governance or democratic practices are not always revealed. This article problematises the development of social capital by rigorously comparing how participation in different types of civil society organisations leads to different kinds of practices.

The article also draws on the ethnic politics literature to highlight how the basis for membership within civil society organisations influences the development of political values and the likelihood of cooperation at the local level. Surprisingly, involvement in the cocoa producer or mutual assistance organisations in Côte d'Ivoire by a group that included members with quite diverse (and politically salient) ethnic, religious, and regional identities did not necessarily create social capital that cross-cut these cleavages. In fact, this more heterogeneous membership base probably hindered the expansion of participatory mechanisms and spurred recurrent organisational crises. In contrast, the more homogeneous membership base of the Ghanaian church groups facilitated the inclusion of greater opportunities for participation, thus supporting the development of more democratic values and practices, albeit initially restricted within particular ethnic and religious groups.

If the development of social capital was limited to the 'private' sphere of voluntary associations and networks, as much of the existing literature tends to assume, then the end result for the mediation of ethnic conflict and prospects for peace in Côte d'Ivoire and Ghana might be more similar than different. Social capital is not solely developed through participation in civil society organisations, however, but also in the spaces for interaction between individuals and the state. Historical processes of state formation play an important role in creating local differences. ${ }^{10}$ Thus, ironically, the social capital developed within ethnically and religiously homogeneous organisations such as the Ghanaian church groups is diversified at the grassroots level due to the availability and legitimacy of political institutions for community decision-making. In contrast, despite the fact that membership in the producer cooperatives and mutual assistance groups is so heterogeneous in Côte d'Ivoire, a lack of political participation within these organisations combines with a corresponding lack of vibrant community-level political institutions to discourage local crossethnic cooperation, and reinforce a more exclusive reliance on vertical, ethnically based patronage networks.

The study is based on 18 months of intensive field research in $1998-99$ in two culturally and economically matched sub-regions on either side of a shared border in West Africa. ${ }^{11}$ After extensive interviews with national, regional and district officials and preliminary site visits, four villages were selected based on detailed criteria to ensure that they were representative of the region and country cases. In each region, sub-groups of the Akan 
While the membership profile of these organisations was relatively homogeneous in terms of ethnicity and, of course, religion (church organisations being dominated by local Akan Christians and mosques being dominated by Moslems who had migrated from either the northern regions of Ghana or Sahelian countries such as Mali and Burkina Faso), the class and gender composition was relatively heterogeneous. In both Ghanaian villages, religious associations included rich and poor, men and women. In fact, women made up perhaps $65 \%$ of church congregations and were generally very active in founding and organising church subgroups.

In addition to the predominant church groups, a variety of other voluntary associations existed in the Ghanaian villages, including an advocacy group for and by the elderly, two agricultural cooperatives, several informal savings cooperatives or 'susu' organisations, and a hometown association. Hence, the overwhelming majority of survey respondents in the Ghanaian villages belonged to at least one, and often several, local associations. However, cocoa farmers were almost totally unorganised in these villages, a difficult position given the recent liberalisation of cocoa prices but reflective of current shifts in cash crop production away from cocoa toward food crops such as tomatoes and cassava (Morris MacLean 2004). While these types of voluntary association have received considerable attention for their dynamism in the literature on Ghana, they generally had even smaller memberships than the church groups and were less active than anticipated. ${ }^{12}$ For these reasons, this analysis focuses on the church groups, a more representative, albeit ethnically homogeneous, type of association in these Ghanaian villages.

In contrast, in Côte d'Ivoire, the few organisations that did exist had much larger and more ethnically heterogeneous membership bases than the many, small church groups in Ghana. ${ }^{13}$ The most notable voluntary association in each village was the cocoa and coffee producers' cooperative (Groupement Voluntaire de Coopération or GVC). While GVCs were originally government-inspired and directed, calling into question the initial 'voluntary' nature of the associations, there had been considerable voluntary regrouping and reorganising of the GVCs in each of the two Ivorian villages. ${ }^{14}$ Each GVG had 50-100 members, mostly men. In addition to being relatively homogeneous in terms of gender, the GVCs were also dominated by larger, wealthier farmers with shared economic interests.

The other large voluntary association in each Ivorian village was the mutual assistance organisation, or mutuelle. These mutuelles are extremely 
common in Côte d'Ivoire, and are usually organised at the instigation of several village cadres in the urban centres, much like hometown associations in Ghana. While each of them claimed to have all of the villagers as members, only a handful had paid the required membership dues. These members were primarily wealthier males with large plantations, civil service salaries or pensions, thus more homogeneous in class terms. Where the Ivorian organisations were notably more heterogeneous than the Ghanaian ones was in terms of their ethnic base. Both the GVGs and the mutual assistance organisations included significant numbers of members from the dominant Akan and minority non-Akan ethnicities found in the village.

In further contrast to Ghana, churches were not the centre of associational activity in Côte d'Ivoire. In the Ivorian villages, the Roman Catholic Ghurch was dominant, with one mosque and one other church struggling to establish itself in each village. The Catholic Church usually had a choir, but any other groups within the church were very small or inactive. Again, women dominated the congregation, but there were fewer outlets for their active participation.

\section{Frequency of meetings and attendance}

The few, large organisations found in Côte d'Ivoire met much less frequently or regularly than the many, smaller associations in Ghana. The survey data confirms a statistical significance $(=0.003)$ in the lower mean frequency of attendance in local voluntary organisations in Côte d'Ivoire than in Ghana.

In Côte d'Ivoire, the mutual assistance organisations usually met as a group only annually. The officers of the group, whose decisions were communicated informally or formally at the annual assembly, conducted all other meetings. The GVC met only slightly more frequently as a group, usually twice a year, once before the long harvest and once at the end. Even the Catholic Church choir met only twice a month at most.

In contrast, in Ghana it was common for members of each church congregation to gather daily for prayer at 5 a.m., by the dim light of a kerosene lantern, before the sun came up and it was time to go to farm. In addition to these daily devotions, each of the Ghanaian church sub-groups met weekly. Since most church members belonged to more than one subgroup, they might meet with other congregation members as frequently as twice daily. While the church groups were visibly (and audibly) the most active in the village, the other voluntary associations also met more regularly than any groups in the Ivorian villages.

\section{Organisational structure and process of decision-making}

Third, the organisational structure and decision-making process of the associations also differed between Côte d'Ivoire and Ghana. In Côte d'Ivoire, most of them were more self-consciously hierarchical, and operated in a top-down fashion. Often, although the top officer was popularly elected, all of the other positions were appointed, much as the Ivorian president appoints his cabinet. In some organisations, even the top officer was not elected, but rather chosen by consensus. Ethnographic observation of meetings revealed that the decision-making tended to be dominated by consensus among existing powerbrokers in the Ivorian organisations, and by voting in the Ghanaian ones. Frequently, members of the leadership explained that this technique was preferable to a democratic vote, as elections caused unwanted divisions and factions in the village. Interestingly, this response echoed a familiar refrain heard in the late I 980 s from the previous single-party leadership justifying resistance to multipartyism in Côte d'Ivoire.

In Côte d'Ivoire, officers frequently took all significant decisions in isolation from the larger group of members who had fewer opportunities to participate in decision-making. For instance, the semi-annual meetings of the GVG usually only pronounced the procedures for the coming harvest or gave an accounting at the end of the harvest. Although a slightly higher percentage of survey respondents in Côte d'Ivoire (I6\%) reported that they participated in the leadership of a local voluntary organisation than in Ghana ( $14 \%$ ), this slight disparity was not statistically significant (significance $=0.5 \mathrm{II})$. This difference probably reflects the more vertical and hierarchical organisational structure of most Ivorian organisations, where each officer had a deputy.

In Ghana, the structure of most associations was less hierarchical and more participatory than in Côte d'Ivoire. There were commonly officers, such as a president, vice-president, secretary and treasurer, but these positions were usually elected by a general vote of the entire membership. Often the vote included at least some element of discretion or secrecy, for example, the candidates were asked to leave the room during a show of hands. The study found that both men and women from a range of class backgrounds were elected to leadership positions. In addition to the election of the leadership in the Ghanaian villages, many decisions were vetted and then brought to a general vote before proceeding. Members frequently justified these practices as an attempt to incorporate the 'new system of democracy' in their organisations. Here again, the study reveals how the rhetoric and experience of the larger political system shapes how 
villagers conceive of organising civil society organisations in contrasting ways in Côte d'Ivoire and Ghana.

\section{Goals and effectiveness of voluntary associations}

In general, the goals of the Ivorian voluntary associations were broader and more ambitious than those of the Ghanaian ones, often focusing on projects for the entire community rather than primarily on their members' needs. The GVCs and mutual assistance groups in Côte d'Ivoire were founded not only to provide assistance in times of need for the contributing members, but also to fund major infrastructure projects for the village. One mutuelle had constructed several classrooms for the school; another had built the school canteen.

In comparison, while the Ghanaian organisations rarely attempted to finance community development, their activities often included a strong element of self-sacrifice for the particular group of members. For example, several churches had welfare funds, where members either gave a monthly donation or worked periodically on a communal farm and contributed the proceeds to the fund. Also, any time a church member was in need, a special offering would be collected at the church, and the congregation would organise to provide frequent visits and social support.

While many of the Ivorian voluntary associations had quite impressive goals and positive intentions, they were, unfortunately, less effective than the Ghanaian groups. Often the broader objectives of the Ivorian associations required a sizable financial base and thus a more burdensome financial participation by the members. Frequently, many GVC members were unable to contribute due to economic hardship, and thus only a minority, or even one lone cadre, provided the necessary financial resources. This often led to a precarious position as the continuation of the organisation's activities depended on one person's volition and oversight. At other times, GVC members chose not to pay their annual dues, as they deemed the leadership untrustworthy.

With more ambitious goals came a larger treasury, which required both more advanced accounting skills and the mechanisms necessary to prevent embezzlement. In one village, widespread mistrust of accounting practices stimulated the break-up of the 'village GVC' into three smaller, separate GVCs. Agricultural extension agents repeatedly encouraged village leaders to reconcile and reunite into one larger and more effective group, but all attempts to date have been unsuccessful. Similarly, in 1999, one mutuelle skipped its annual meeting, due to a lack of financial participation and cohesion. Ivorian leaders frequently recounted long histories of the repeated creation and dissolution of previous organisations with similar goals.

In comparison, partially because the group objectives were more limited in Ghana, the required financial contributions were not as burdensome; thus most members were able and willing to participate. The survey data confirmed that the mean financial contribution of Ghanaians was slightly lower than for Ivorians. Furthermore, the Ghanaian organisations generally lasted longer and experienced fewer factions or breakdowns than their Ivorian counterparts.

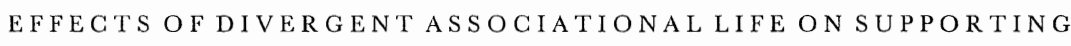

The above differences in the organisation of local voluntary associations result in different types of local political values and practices, with important implications for the mediation of potential ethnic conflict at the grassroots, and for the prospects of democracy at the local and national levels. Ironically, the more ethnically heterogeneous associations in Côte d'Ivoire hindered genuine political participation and democratic decisionmaking, strengthening traditional hierarchies and hardening social and political exclusion along ethnic lines. In contrast, participation in more ethnically homogeneous church groups in Ghana offered more frequent and genuine opportunities for individuals to 'practice democracy', thereby providing enhanced support for the development of democratic values, and ultimately, greater capacity and interest in cross-ethnic cooperation for local problem-solving. Thus, it is not the association itself that is acting to mediate ethnic tensions at the grassroots, but rather, how individual association members gain new sets of political skills and values that they then bring to other political contexts. While this article highlights the organisation of civil society, it is not the only factor shaping political values. Divergent experiences of the state at the local level both interact with the organisation of civil society, and exert an independent effect on the development of local political values and practices. ${ }^{15}$

A key issue that troubles many studies dealing with democracy is how to define and measure the concept. ${ }^{16}$ Democracy will be defined here broadly as a political system where the members participate in the decision-making of their community. In order to ascertain the extent of democratic values and practice in Ghana and Côte d'Ivoire, three areas will be compared below: (I) the conceptualisation of the state-society relationship, including the rights and obligations associated with citizenship; (2) the salience and organisation of local politics; and (3) the mechanisms for making claims from the local to the national level. 


\section{Conceptualisation of the state-society relationship}

First, the experience of interacting in different types of local associations is an important factor in shaping the divergent ways that Ivorians and Ghanaians conceptualise the state-society relationship and the parameters of citizenship, both locally and nationally. Generally, Ivorians tended to view the state in more personalised terms, as an organisation that should deliver an expansive list of entitlements to citizens with very minimal acknowledgement of reciprocal duties. In contrast, Ghanaians perceived the state in terms of a civil administration that should provide certain public goods and services in exchange for community-organised efforts to develop the country. This more community-oriented notion of citizenship in Ghana than in Côte d'Ivoire facilitates the resolution of any ethnic tensions at the village rather than the national level.

\section{Conceptualisation of the state}

When describing the state, Ivorians and Ghanaians mentioned different units or levels of administration or authority. Ivorians defined 'state' almost immediately in terms of individual political authorities, not the civil administration. Only one person mentioned civil servants as the state; everyone else interviewed mentioned politically elected or appointed officials such as the mayor, préfet, ministers, president, etc., frequently referring to individual politicians by name, rather than by their offices. In contrast, Ghanaians repeatedly used the word 'government' in their descriptions, seemingly referring to the civil administration or bureaucracy as a whole. ${ }^{17}$

Ivorians and Ghanaians also differed in their descriptions of the relationship between the state and local people. While both Ivorian and Ghanaian respondents described a paternalistic state, in Côte d'Ivoire a more straightforward, top-down paternalism of the state as 'guardian' seemed to reinforce the perception of unequal levels of power between the state and local people. One village resident highlighted the tension between the commonly espoused ideal of the 'state as all of us' and the reality of an abysmal lack of connection between the state and the villagers: ${ }^{18}$

The state is all of us. But, our elected officials do not come to the source for their information, let's say, regarding our key problems ... M. Brou Emile, President of the National Assembly, doesn't even know here in Opanin. He takes decisions all by himself, and we don't like that. Otherwise, the state is all of us.

This lack of connection between elite decision-makers and masses seemed to be paralleled in everyday village politics in Côte d'Ivoire, particularly when it came to non-indigenous populations. For example, when 'thieves' from outside the village attempted to burgle a nonindigenous cocoa farmer, the exclusively indigenous elders gathered together in a closed meeting to discuss the problem and create a village security patrol. Based on participant accounts, there was little or no nonindigenous input into the village effort to protect itself, despite the fact that the actual incident provoking the meeting involved a non-Akan family, and, further, that the most 'vulnerable' residents living on the village's edges were non-Akan.

In comparison, Ghanaians frequently articulated their notion of paternalism within a familial idiom of reciprocal duties between the 'father' and his children. 'The elders or big people should do their part for us; the children, too, to do our part. ${ }^{, 19}$ This familial idiom seemed to be extended at the village level to include non-indigenous chieftancies and village residents. Even at funerals for Akan residents in the Ghanaian villages, nonindigenous residents were included in the planning and financing of the event, and non-indigenous chiefs were given places of honour, albeit (of course) subordinate to the Akan village chief. In contrast, in Côte d'Ivoire, the non-indigenous chieftancies were not as integrally incorporated in funeral planning, and then, when their 'voluntary' contribution was judged inadequate, Akan residents complained of their insulting lack of respect for the Akan system of governance.

\section{Local notions of the rights of citizenship in Ghana and Côte d'Ivoire}

Consistent with the finding that Ivorians and Ghanaians conceive of the state in different terms, the research suggests that they have developed varying notions of the rights and duties of citizenship. ${ }^{20}$ Again, the divergent local practices associated with local voluntary associations are not the only factors in shaping local conceptualisations of citizenship; nevertheless, since the comparison of these regions controls for so many variables, the finding of a relationship is a useful starting point for further research in this area. ${ }^{21}$

Perceptions of the rights of citizenship differ in two important ways in these regions of Côte d'Ivoire and Ghana (see Table I). First, Ivorians were apt to have a much more expansive view of the state's role in their lives, often presenting a long list of entitlements owed to them from an omniscient and omnipotent state. For example, one 40-year-old Ivorian man ticked off several things that the state should give him and then summarised by saying that the state should provide 'everything I need' ${ }^{22}$ In contrast, Ghanaians tended to respond with a relatively restricted list of 
TABLE I

Comparison of perceptions of citizens' rights in Ghana and Côte d'Ivoire

\begin{tabular}{|c|c|c|}
\hline & Côte d'Ivoire & Ghana \\
\hline Perception of rights & Expansive list of entitlements & $\begin{array}{l}\text { Restricted list of rights linked } \\
\text { explicitly to duties }\end{array}$ \\
\hline $\begin{array}{l}\text { Nature of goods } \\
\text { delivered by state }\end{array}$ & $\begin{array}{l}\text { Private goods consumed by } \\
\text { individuals }\end{array}$ & $\begin{array}{l}\text { Public goods consumed by } \\
\text { communities }\end{array}$ \\
\hline $\begin{array}{l}\text { Three most frequently. } \\
\text { mentioned rights }\end{array}$ & $\begin{array}{l}\text { Individual loans }(28 \%) \\
\text { Cash grants to needy }(20 \%) \\
\text { Housing }(16 \%) \\
\text { Employment (16\%) }\end{array}$ & $\begin{array}{l}\text { Social services }(33 \%) \\
\text { Employment }(24 \%) \\
\text { Roads/markets/electricity (21 \%) }\end{array}$ \\
\hline $\begin{array}{l}\text { Extremely low scores } \\
\text { on 'classic' } \\
\text { citizenship rights } \\
\text { associated with } \\
\text { Western democracies }\end{array}$ & $\begin{array}{l}\text { Provision of physical security }(2 \%) \\
\text { Protection of private property }(0 \%) \\
\text { Protection of equality }(0.4 \%) \\
\text { Guarantee of freedom }(2 \%) \\
\text { Freedom to participate in } \\
\text { political processes }(0.4 \%)\end{array}$ & $\begin{array}{l}\text { Provision of physical security }(2 \%) \\
\text { Protection of private property }(\mathrm{I} \cdot 5 \%) \\
\text { Protection of equality }(\mathrm{I} \%) \\
\text { Guarantee of freedom }(0.6 \%) \\
\text { Freedom to participate in political } \\
\text { processes }(0 \%)\end{array}$ \\
\hline
\end{tabular}

rights that were frequently linked in the same sentence to corresponding duties. For example, one survey respondent replied, 'I would do anything I am asked to do, be it payment of money (taxes), etc., if only that will help to improve education. ${ }^{23}$ This finding strengthens the earlier evidence of a more explicit view of reciprocity between the state and citizens in Ghana than in Côte d'Ivoire.

Second, the nature of the rights owed to citizens differed in Côte d'Ivoire and in Ghana. In contrast to the largely community orientation of the rights described by Ghanaians, every one of the rights most frequently mentioned by Ivorians related to private goods consumed by individuals. For example, the most frequently cited right in Côte d'Ivoire was that the state should provide loans to individuals $(28 \%)$ for individual farm expansion or enterprises. Consistent with the earlier point about more expansive entitlements, almost as many Ivorians $(20 \%)$ asserted that the state should 'give me some money' as outright cash grants instead of credit. In addition to housing ( $16 \%$ ) and employment (16\%), Ivorians frequently included food and even various individual consumer goods as something the state should give to citizens for free. For example, one Ivorian declared in all seriousness, 'The state should buy me a car, purchase me a refrigerator, and build a house for me. ${ }^{24}$

Meanwhile, it seems that Ghanaians conceptualised their rights as citizens in terms of public goods that the state provides to communities, such

$$
\text { T A B LE } 2
$$

Comparison of duties of citizens in Ghana and Côte d'Ivoire

\begin{tabular}{|c|c|c|}
\hline & Côte d'Ivoire & Ghana \\
\hline Perception of duties & $\begin{array}{l}\text { Concept of obligations more } \\
\text { difficult to grasp }\end{array}$ & $\begin{array}{l}\text { Explicit notion of } \\
\text { reciprocity }\end{array}$ \\
\hline $\begin{array}{l}\text { Nature of duties owed to } \\
\text { the state }\end{array}$ & Performed as an individual & $\begin{array}{l}\text { Performed together as a } \\
\text { community and/or to } \\
\text { benefit the community }\end{array}$ \\
\hline $\begin{array}{l}\text { Three most frequently } \\
\text { mentioned duties }\end{array}$ & $\begin{array}{l}\text { Work on individual farm }(58 \%) \\
\text { Participate in politics (10 \%) } \\
\text { Develop community/ } \\
\text { country (10 \%) }\end{array}$ & $\begin{array}{l}\text { Develop the community/ } \\
\text { country }(47 \%) \\
\text { Pay taxes }(22 \%) \\
\text { Perform communal labor }(21 \%)\end{array}$ \\
\hline $\begin{array}{l}\text { Extremely low scores on } \\
\text { 'classic' citizenship duties } \\
\text { associatedwith Western } \\
\text { democracy }\end{array}$ & $\begin{array}{l}\text { Pay taxes }(8 \%) \\
\text { Obey laws }(7 \%) \\
\text { Serve the military }(0 \%)\end{array}$ & $\begin{array}{l}\text { Participate in politics }(7 \%) \\
\text { Obey laws }(3 \%) \\
\text { Serve the military (o \%) }\end{array}$ \\
\hline
\end{tabular}

as social services or the construction of roads. An analysis of the three most frequently cited rights by survey respondents in Ghana and Côte d'Ivoire illustrates the above pattern vividly. In Ghana, one third of the survey respondents $(33 \%)$ said that citizens had a right to the provision of social services, often free or low-cost education or health care. ${ }^{25}$ Only Io $\%$ of respondents replied similarly in Côte d'Ivoire. This Ivorian sense of individual entitlement served to reinforce the ethnically based patronage system rather than foster a multiethnic conception of community as in Ghana.

\section{A comparison of the duties of citizenship in Ghana and Côte d'Ivoire}

Ivorians and Ghanaians tend to think about the duties of citizenship in distinct ways that parallel the patterns found above (See Table 2). First, while Ivorians tended to dwell on entitlements and then struggle longer with the concept of duties, Ghanaians linked rights and duties explicitly in descriptions of reciprocity with the state. As one Ivorian exclaimed, 'It's us that don't have anything. Who should help the state, and why?!'26

Second, the nature of the duties owed to the state continued to be more individually oriented in Gôte d'Ivoire and community oriented in Ghana. The most frequently cited reply in Côte d'Ivoire was 'to work on the respondent's individual farm' $(58 \%)$, whereas the most frequently cited response in Ghana was 'to work to develop the community or country as a whole' $(52 \%)$. As one Ivorian explained, 'Every morning, I go to the farm. This is all that I can do for the state. ${ }^{27}$ Almost all of the Ivorian 
respondents spoke in terms of how the state benefited from their individual cash crop production, but almost never in terms of how their individual food crop production increased the food security of the nation as a whole, as so many Ghanaians did.

Another indicator of a more community oriented conceptualisation of duties in Ghana is that over three times as many Ghanaian respondents $(22 \%)$ mentioned the obligation to pay taxes as Ivorians $(7 \%)$. Ghanaians not only mentioned taxation more frequently, but almost always put it in the context of reciprocity for state-provided services. For example, several Ghanaians asserted that citizens should pay taxes in return for the state's efforts to create jobs, provide free medical care and free education. In contrast, while several Ivorians indirectly referred to state taxation of their cash crop production, very few directly discussed paying taxes to the state as an obligation. They only spoke of payment to the state in highly personalised and ceremonial terms to acknowledge state representatives visiting the village, for example, giving a sheep to honour a visiting politician. In general, the comments by Ivorian respondents illuminated a popular sense of submission vis-à-vis a dominant state, and lacked any notion of representation or reciprocity.

Lastly, the contrasting perceptions of communal labour in Côte d'Ivoire and Ghana revealed dramatically the nature of citizenship in the two cases. In Côte d'Ivoire, fewer than $1 \%$ of all respondents mentioned communal labour, whereas in Ghana communal labour was noted explicitly by almost 21 \% of respondents. In Côte d'Ivoire, communal labour seemed to be viewed negatively, as an indicator of state failure. When one Ivorian respondent described how the 'cadres' had organised the village to construct several school classrooms, he was openly resentful of the village's forced assumption of what he viewed clearly as a state responsibility. ${ }^{28}$

In comparison, one long-time resident of Makwan, Ghana, explained the commonly shared view that a degree of local participation and selfreliance was necessary and positive: 'The citizens are too many for the state to be able to help, so the citizen should rather do something to improve their lot instead of relying on the state. ${ }^{29}$ During the time of fieldwork in both Ghanaian villages, the chief or local unit committee (a group of popularly elected village residents who manage village problems and represent the village at the district level) frequently organised work groups to facilitate a government-sponsored electrification project, provide labour for the construction of a school building, or make preparations for a funeral. Usually, the gong-gong beater would announce ahead of time that residents from a particular side of the road would work one day, and from the other side, the next. Opinion in both Ghanaian villages was that participation in communal labour was high, enforceable, and evenly distributed among residents. In particular, no one in Ghana ever claimed that a greater burden of communal labour was imposed on certain ethnic groups. In contrast, in Côte d'Ivoire, several chiefs representing migrant ethnic groups complained that the village chief only consulted them when some onerous task needed to be accomplished for the rest of the village.

To summarise, the political structure and practice of ethnically homogeneous church groups in Ghana strengthened the development of more democratic values than in Côte d'Ivoire in terms of greater political participation by a larger number of individuals in the decision-making of the community. Even though Ghanaian church group members might not interact with individuals from other ethnic groups within their church activities, they spoke of their expanded appreciation of 'democracy' and 'participation', and expressed a greater toleration of differences of opinion. The values forged through their associational participation then influenced the ways that everyday issues were approached in the village chieftaincy or unit committee. Thus, in Ghana, the various non-indigenous ethnic groups were routinely included in the planning for village events, whereas in Côte d'Ivoire, conflict was sparked over how the nonindigenous groups were participating (or not).

\section{Differences in the salience and organisation of local politics in Ghana and Côte d'Ivoire: irrelevance in Côte d'Ivoire versus growing importance in Ghana}

The divergent structure of voluntary associations shapes how local political institutions are viewed and evaluated by village residents in Côte d'Ivoire and Ghana, with important implications for how they mediated ethnic tensions on an everyday basis. Generally, the more active church groups in Ghana reinforced more frequent social interaction between members of different extended families, classes and genders in the same village community, which made local politics, including political party organisation, more active, salient, and openly heterogeneous. In contrast, the less active associations in Côte d'Ivoire strengthened ties between members of the same nuclear and extended family or members of the same class. These vertical ties also extended more frequently outside the village community, more tightly linking urban cadres with village residents, making local politics less salient, and fostering a more top-down organisation of state institutions and political parties in Côte d'Ivoire than in Ghana. 
Again, this article does not dismiss how divergent histories with local and national state institutions directly influence villagers' evaluation of local institutions' relevance. Instead, it seeks to highlight how experiences in local associations can parallel and reinforce these legacies, resulting in even sharper distinctions between Côte d'Ivoire and Ghana, a dynamic that is often missed and even more rarely brought to bear on the issue of mediating potential ethnic conflict at the grassroots.

\section{Salience of local state political institutions in Ghana and Côte d'Ivoire}

Evidence from the survey research suggests that Ghanaians placed more value on local political institutions than did Ivorians. In general, Ghanaians noted representatives of the most local-level state and 'traditional' political institutions as the most important leaders for village development, whereas Ivoirians mentioned individuals who were not necessarily locally based. In Ghana, the unit committee $(82 \%)$, the village chief $(55 \%)$, and the District Assembly (24\%) were cited the most frequently as the most important leaders for development. In contrast, demonstrating a lack of confidence in local-level political institutions, Ivorians mentioned the chief much less frequently $(25 \%)$, and rarely mentioned the most local political authority, the sous-préfet $(4 \%)$ or mayor $(6 \%) .{ }^{30}$ Instead, most Ivorians (5I \%) cited, often by name, wealthy civil servants ('cadres') as being the most influential person or group for the development of their community. The second most frequently identified leaders of village development were simply 'the rich' ( $16 \%$ ), or large cocoa farmers (II \%), neither of which were ever cited in Ghana. The comparison of this frequency of responses demonstrates dramatically the confluence of economic and political power that is rooted in personal wealth and achievement in Côte d'Ivoire, rather than any elected or appointed local office, as is the case in Ghana. Because the above political and economic exclusion in Côte d'Ivoire reinforces major ethnic, religious and regional divisions in the country, and since local political institutions are either absent or irrelevant, conflicts over power and resources tend to become national crises framed in terms of a zero-sum game between various ethno-regional groups.

Examples from each country demonstrate how the different value placed on local institutions either helped or hindered the resolution of ethnic tensions in the village. First, an incident during the period of my fieldwork in Barima, Ghana, reveals how a more powerful role for the chief helped to resolve an ethnic conflict before it became violent. When my non-indigenous research assistant was accused by a village resident of
POLITICAL VALUES IN CÔTE D'IVOIRE AND GHANA

genital shrinking, the potential for escalation was stymied by the village chief's insistence that the matter be resolved immediately by him, his elders, and the concerned parties in his 'traditional court' in the village, not taken to the district capital. The effort to bring everyone together quickly and publicly in a calm atmosphere served to rapidly infuse the rumours circulating throughout the village with more accurate information, and to provide a mechanism for village-wide reconciliation. In comparison, in Côte d'Ivoire, when the local GVC was immobilised by accusations of embezzlement, levelled primarily in ethnic terms at the non-indigenous treasurer, the village chief quickly passed the problem up to the regional government for their intervention. The result was interminable delays, a lack of public information, and hence the rumours and ethnic tensions continued to swell.

\section{Local-level political party organisation}

Although respondents in both Côte d'Ivoire and Ghana hardly ever mentioned political party officials as key leaders of village development, the different ways in which political parties are organised at the local level are influenced by the differences in the organisation of local associations. ${ }^{31}$ Paralleling the patterns seen earlier with local associations, political party meetings and activity seemed to be much less frequent and institutionalised at the village level in Côte d'Ivoire. Representatives of the ruling party acknowledged that they only met regularly immediately prior to elections. Even then, the party appeared to focus on organising small festivals and rallies to receive visiting party bosses from Abidjan. These visits also appeared to be largely initiated by the regional and national party officials, not the village representatives. The opposition parties were beginning to get organised for the 2000 elections, but much less energetically than in Ghana. The Rally for a Democratic Republic (RDR) appeared to be quietly establishing initial village cells, but there was no official representative (as for the then-ruling PDCI), and there were no regular meetings. Opposition activity was also conducted in a tenser atmosphere of greater secrecy in Côte d'Ivoire than in Ghana. Opposition party representatives claimed that there were actually more party members in the village, but that local people were fearful of declaring openly their opposition to the long-dominant PDCI. ${ }^{32}$ Without much evidence from political activity in the public realm, many village residents simply ascribed particular party loyalties to their neighbours, wholly based on their ethnicity or place of origin. ${ }^{33}$ Given the uneasy political atmosphere, these assumptions only served to increase tensions and divisions between the different ethnic communities. 
In comparison, the Ghanaian villagers were more actively and continuously involved in local political party organisations than their Ivorian counterparts. During the time of the field research in 1998-99, the opposition party representatives (in particular, the New Patriotic Party or NPP) appeared to be the most active, organising informal weekly meetings over a year and a half in advance of the 2000 elections (which the NPP won). These meetings included some limited discussion of programmatic issues, but focused largely on local party strategy to win voters, increase voter participation, and eliminate electoral manipulation and fraud. Local party leaders also tried to institutionalise the party organisation at the village level by opening up party offices in each village. The district offices actively supported these developments by organising events to inaugurate the new headquarters of the party's village cell. Ironically, the then-ruling party (the National Democratic Congress or NDC) seemed less active with regard to village-level organising. Party representatives in the village described extensive factionalisation within the district branch of the ruling party, paralleling divisions at the national level and hindering organisation. It is important to note, however, that none of these divisions within the local NDC or the other opposition parties were organised along ethnic lines. Any ethno-regional bases for the Ghanaian national parties, arguably weaker to begin with in Ghana than in Côte d'Ivoire during this period, were further blurred at the village level where the relevant ethnicities were not proportionally represented as in the national population.

To summarise this subsection, in Côte d'Ivoire, since producer cooperatives and mutual assistance groups rarely met, and when they did assemble, participation was more limited, there were fewer opportunities for social interaction across different categories of ethnicity or class, despite their more ethnically heterogeneous membership base. The more vertical and hierarchical nature of associations reinforced the social and political exclusion of poor families versus rich ones, inducing a narrower type of social trust that was less likely to lead to coalition building across the community. Since chieftaincy institutions are relatively weak, no elected political institution exists in Ivorian villages, and local political party organisation is minimal, individuals had little incentive or capacity from any realm to solve problems at the community level. ${ }^{34}$ Frequently, individuals and groups proceeded directly to their personal contacts (almost exclusively within their own ethnic group) positioned in the higher echelons of the political system.

In contrast, in Ghana, since local church groups met more frequently, greater opportunities for social interaction existed at the local level. While the basis of these ties was relatively homogeneous in terms of ethnic, religious and/or regional identity, the social linkages across categories of gender and class provided greater opportunities to gain knowledge and develop confidence of individuals who belonged to groups outside one's extended family than those organisations in Côte d'Ivoire, which superficially appeared more heterogeneous. Furthermore, the more participatory nature of these voluntary organisations provided individuals with little prior political and/or economic status with new and more frequent opportunities to voice their opinions and exercise leadership. This more active and heterogeneous local social and political experience in church groups combined with the availability of viable local political institutions such as the chieftaincy and unit committee, to encourage a greater willingness and capacity to come together to resolve community problems at the local level, rather than skipping to higher levels in the political system. The unit committee, in particular, included a diversity of elected members, including men, women, youth, and non-indigenous ethnic groups. Local political institutions and local capacity for conflict resolution is thus stronger in Ghana than in Côte d'Ivoire, a key reason why the potential for ethnic conflict has remained more localised in Ghana, and has not erupted into a national crisis as in Gôte d'Ivoire.

\section{Practice of politics at the national level: linking the local upward in Ghana and Côte d'Ivoire}

The character of local associations in Ghana and Côte d'Ivoire not only shapes how people view the relevance of local political institutions in different ways, but also how they organise politics at the national level. Rather than relying on problematic statistics of voter participation, ${ }^{35}$ this study compares village organisation and everyday political practice which link the local to the national level. While existing scholarship highlights the important role of clientelist networks for the state in Africa (Bayart I993; Hyden 1983), rarely is the character of local associations connected explicitly to the nature of the broader patron-client system at the national level. In Côte d'Ivoire, the greater dependence on cadres based in the national capital for leadership, accountability, and financing strengthened a more nationalised patron-client system. Meanwhile, in Ghana, the more village-centred leadership, governance, and funding of associations reinforced a more localised patronage system. Thus, social ties linked village residents more frequently and directly to the national capital in Côte d'Ivoire than in Ghana, where clientelist ties tended to be denser within the village or at most within the district. 
Thus, in Côte d'Ivoire, the channels for making political demands were relatively narrower, more vertical, and ethnically homogeneous; village residents depended on one or two cadres from their own extended family, and thus their own ethnic group, and contacted them directly in Abidjan when something was needed. One Ivorian woman declared succinctly, 'If you have problems, those who work in Abidjan can help resolve the problem. ${ }^{36}$ This is not unusual given the lack of locally available political institutions discussed earlier. Despite comparable travel times to the regional and national capitals as in Ghana, the clientelist networks in the Ivorian village usually skipped the closest levels of the political system in order to appeal directly to the top via one personal contact. "The government doesn't intervene here (in the village). It's necessary to have a person on high over there in order to have something. ${ }^{37}$ Still, simply because these clientelist networks were more personalised in Côte d'Ivoire, does not mean that they are necessarily more open, inclusionary, or flexible. In Côte d'Ivoire, social connections clearly overlap with economic and political power from the local all the way up to the national level. The patrons one could contact were almost always within one's own extended family (and ethnic group), and contrary to most assumptions in the literature, often whole extended families were relatively rich or poor. 'We, the poor, who don't have anyone in Abidjan, get less help and those who have contacts, and above all, those who have money get more help. ${ }^{38}$ Many Ivorian respondents lamented that because they were 'unknown' by political officials, they were 'powerless' to make any claims or express their interests in any way, an experience described by one young man as being 'blind and deaf'. ${ }^{39}$

In contrast, clientelist networks appear to be more localised in Ghana. Strengthening the localisation of clientelist networks at the national level in Ghana are two factors: (I) the history of fear and intimidation of state authority, particularly during the early years of Rawlings' rule; and (2) the lack of linkages that 'scale up' from the local to the national level. ${ }^{40}$ Revealing both factors, one Ghanaian woman commented, 'If we could take these issues up there (Accra), we would have gone.' ${ }^{41}$ Instead of skipping to the national level, villagers frequently took their problems to the Unit Committee. ${ }^{42}$

If a problem persisted or a higher level of intervention was necessary, often villagers travelled to the district assembly to meet district officials. Sometimes the villagers went to the district capital with a Unit Committee member or the elected District Assemblyman from their village, but often they represented themselves at these meetings. It is impossible to know what proportion of these meetings could be characterised as clientelistic without being able to observe them. Still, it is observable that villagers (or clients) visited local political officials (their patrons) on the two levels of the political system closest to them. It seemed relatively rare for village residents to be willing and able to make the trip to either the regional ( $\mathrm{I}$ hour travel time) or national capital ( 5 hours travel time). And, even rarer, that someone else was able to facilitate that contact to a higher order political official.

To summarise, this section illustrates a remarkable divergence in the local values and practices of democracy in similar villages in Côte d'Ivoire and Ghana. The differences between the two cases in the conceptualisation of the state-society relationship, the salience and organisation of local politics, and the mechanisms for making claims on the national political system reveal a consistent pattern where political participation and decision-making is relatively inactive and exclusive at the local level in Côte d'Ivoire compared with Ghana. The organisation of local associational life is an important factor in shaping (and often reinforcing) the development of contrasting local political values. These findings have important implications for the mediation of ethnic conflict both at the grassroots and at the national level.

\section{米}

To conclude, differences in the organisation and practices of local associations in similar villages in similar regions of Côte d'Ivoire and Ghana have combined with different experiences of the state to produce divergent sets of political values and practices in the larger political system. Thus, there are important distinctions to be made about the character of grassroots associations, particularly with regard to their effects on 'making democracy work'. In Côte d'Ivoire, despite the promise of a more heterogeneous membership base, the structure of associations restricted popular participation over decision-making, and, perhaps, stunted the development of democratic values and practices at the local level. Instead, the significant financial contributions of a few individuals usually translated into substantial political power in local organisations, which weakened accountability and transparency. Thus, despite the greater ethnic, religious and regional heterogeneity of the membership of Ivorian organisations, their limited activity and opportunity for social interaction combined with the greater rate of organisational failure to undermine trust of other groups instead of increase it. Furthermore, few viable political institutions existed at the village level in Côte d'Ivoire to counter this lack of political participation in local decision-making. Consequently, Ivorians tend to be less 
connected to their community in their everyday interactions, and the focus of politics shifts to their individual abilities to access powerful patrons within their own ethnic group, particularly within their own extended family system. This ethnically based patronage system not only reinforces the economic and political salience of ethnic identity today, but crowds out the possibility of building multiethnic mechanisms of conflict resolution in the future.

In contrast, in Ghana, many more individuals participated almost daily in the decision-making of local church groups. While these church groups were relatively homogeneous in terms of ethnic, regional and obviously religious identities, there were genuine opportunities for social interaction and decision-making between men and women belonging to different classes and extended family systems. While the social capital developed within the Ghanaian organisations did not cut across all social cleavages in the village community, it was nevertheless an important resource, providing Ghanaian villagers with the confidence, skills and willingness to participate and resolve conflicts first at the local level. This initial inclination to solve problems locally, combined with the availability of legitimate village-wide political institutions, meant that Ghanaians tended to conceptualise the state-society relationship and shape the political arena primarily in terms of the local community rather than as ethnically based linkages to the national capital.

This study attempts to move beyond an analysis of village political organisation to reveal an important, yet understudied connection between grassroots political development and the mediation of potential ethnic conflict at the local and national levels. When Ivorian villagers rely on the personal power of local and urban-based economic elites to make decisions and organise politics, ethnically based social exclusion in the political realm is reinforced. Many Ivorians report that there is no longer any reason to buy into local or national-level political institutions. This high level of frustration, with no viable outlet for direct political participation, provides an important context for understanding the December I999 coup d'état and subsequent ethnic violence in Gôte d'Ivoire. This perspective of grassroots political organisation and development reveals that the civil war did not emerge out of nowhere, and was not simply provoked by worsening economic times; rather, the conflict is grounded in a longer history of ethnically based political exclusion. Even during the earlier 'good times' of the 'Ivorian miracle', when northerners and foreigners were welcomed to come and work on Ivorian cocoa and coffee plantations, and virgin land was in greater abundance, local cross-ethnic political participation and thus the possibility for conflict resolution was severely limited. Recent economic hard times have merely helped to open the Pandora's Box, transforming politics into a zero-sum game between larger, ethno-regional factions. Unfortunately, the absence of experience with local-level ethnic cooperation and this longer legacy of political exclusion will probably make the mediation of Côte d'Ivoire's civil war even more challenging and difficult.

The outlook in Ghana, although far from perfect, is relatively more hopeful. Ghanaian villagers report that local avenues for political participation and problem resolution do exist. While clientelist networks remain important, they often pass through local government channels, arguably reinforcing the strength of local politicians rather than bypassing or superseding them. It is likely that these more legitimately rooted local institutions help mediate the potential for ethnic conflict at the local level and then prevent ethnic divisions from destabilising the national political system. Still, the lack of effective linkages upward from the village to the national political system is a problem that must be resolved for genuine long-term political stability in Ghana. The potential for disarticulation between democracy at the grassroots and for the nation remains disquieting.

\section{NOTES}

I. Côte d'Ivoire adopted a multiparty system under long-time President Houphouet-Boigny in 1990 (Widner 1994), and Ghana moved to multipartyism in $199^{2}$ (Herbst 1994).

2. In Ghana, in March 2002, a long-standing chieftaincy dispute between two rival clans resulted in approximately $3^{1}$ deaths and over 3,000 displaced people in Northern region. In October and November 2002, communal clashes between local ethnic resulted in 9 deaths and 336 displaced persons. Both of these conflicts originated over relatively minor disputes over property or accusations of petty theft. (www.irinnews.org). In none of the above cases does it appear that the conflict spread beyond the borders of those ethnic communities directly involved, nor was the source of the conflict a dispute over the legitimacy of the national government.

3. For example, Woods (2003) correctly emphasises the role of increasing land pressure and labour costs in sharpening ethnic tensions in Côte d'Ivoire. While a cross-national perspective on the Ivorian and Ghanaian governments' historically different immigrant labour policies would further support his argument, it remains necessary to see how these structural pressures may be channelled differently given the variations in local associations and political institutions.

4. Some of the early work on civil society (Chazan 1992; Diamond 1988) was criticised for assuming that civil society organisations were participatory and democratic (Callaghy 1994; Kasfir 1998). Similarly, some of the social capital literature (Putnam 1993) has been criticised for not distinguishing between different types of social capital (Fine 200I).

5. Again, Varshney's research design is exceptional in that he examines the role of civil society in cities with and without communal violence.

6. Such rigorous empirical investigation not only disentangles the concept of civil society from democracy, but also problematises the development of social capital, addressing one of Levi's (1996) criticisms of the social capital literature.

7. The fact that this study and VonDoepp's report such opposite findings for decentralised Protestant church groups reinforces the necessity of looking within organisations rather than making assumptions based on organisational forms.

8. This dynamic and mutually constitutive process is similar to what Migdal (200I) describes as a 'state in society' approach. 
9. Fine (200I) and Evans (1996) make a similar point that the concept of social capital must include an analysis of differentials in power, which can lead to conflict, domination, and exclusion, not necessarily 'positive' outcomes.

Io. Tarrow (I996) critiques Putnam's work for not examining an important prior causal factor, the effect of different patterns of state building.

II. Fieldwork was conducted from April to August 1997 and from October 1998 to October 1999 in two similar villages in Tano District in the Brong-Ahafo region of Ghana and in two similar villages in the Abengourou region of Côte d'Ivoire. Fictional names are used for these villages in the footnotes to protect the anonymity of the sources. These two regions were selected to highlight the cross-national comparison and not because they were nationally representative. Considerable regional variation exists in both Cote d'lvoire and Ghana. The pattern of variation is also similar in both countries in religious and ethnic composition of the population. In very general terms, the regions chosen were both in transition forest zones with continued reliance on cocoa production, perhaps slightly better than average levels of wealth and infrastructure, and a more predominantly Akan, Christian population. It is notable that while both regions are considered 'southern', they are both located in the centre of each country and straddle the north and south in multiple ways. The author's limited field experience and knowledge of other regions in each of the country cases suggests that the broad similarities between different region within each country might be more significant than the differences. Stronger inferences about 'national' differences would require further fieldwork in additional regions and may be investigated in future research.

12. The exception was the elderly advocacy group, which was aggressively expanding its mem12. The exception was the elderly advocacy group, which was aggressively expanding its mem-
bership during the time of the fieldwork. Still, because the organisation was in its infancy, based in the bership during the time of the fieldwork. Still, because the organisation was in its infancy, based in the
regional capital an hour away, and there were few activities that brought members together within the village, the study retains its focus on the church groups.

13. In contrast to Ghana, where the only youth groups were connected to religious organisations, in Côte d'Ivoire there were many relatively small youth groups in each village. This is an interesting exception to the general rule that Ghanaian voluntary associations are more numerous but with smaller membership bases.

14. While there was an element of government supervision over the GVC most directly linked to government, this monitoring was sporadic and extremely distant (to even say it was 'arm's length' would imply a cosier proximity than existed). The village members were directly responsible for the 'government' GVC's governance structure and accountability (or lack thereof). 'Government' GVCs had been dissolved and then reformed on the initiative of village residents, not any government agency. Village leaders had also broken off and formed new GVCs on their own.

I5. For example, Morris MacLean (2002) describes in detail how experiences of colonial state formation influence the conceptualisation of the state-society relationship in the provision of social support, thereby shaping the development of colonial and post-colonial social policies.

I6. Collier \& Levitsky (1997) illustrate the extent of conceptual stretching in this field with their work on 'democracy with adjectives'. 17. While the divergent ways that Ivorians and Ghanaians experience the state at the local level is obviously important in shaping the above terminology and underlying conceptualisations, the differences revealed earlier in the way that local associations are organised parallel and reinforce this variation in political value development. It is precisely this dynamic interaction between state, society and local associational life that is understudied, particularly in Africa, where state, society and civil society are often conceptualised in conflictual terms.

I8. Men's focus group (tape recording), Opanin, Côte d'Ivoire, September 1999.

19. Women's focus group (tape recording), Barima, Ghana, March igg9.

20. While citizenship is a concept that does not readily translate into the local Akan languages used in Ghana and Côte d'Ivoire, the idea of reciprocity is not culturally foreign. Thus, citizenship was understood easily as the reciprocal rights and duties of villagers vis-à-vis the state. Efforts were made to emphasise that the question being asked was, 'What does the state owe you?', and not, 'What do you want from the state?

21. It is noteworthy that Ghanaian and Ivorian respondents almost never mentioned the rights and obligations 'classically' associated with citizenship in advanced industrialised democracies in the US and Western Europe. Thus, $2 \%$ or fewer of respondents in each country mentioned the right to freedom, equality, political participation, or the protection of private property. Similarly, very few respondents cited duties to obey the laws of the state or serve the military. Even when Ghanaians respondents cited duties to obey the laws of the state or serve the military. Even when Ghanaians
mentioned paying taxes or Ivorians described their duty to participate in the political process, the response rate was well behind the most frequent replies. This insight demonstrates how differen political histories, including different everyday experiences interacting with local associations and the state, shape how people develop their own conceptualisation of the state--society relationship (Gore 1995; Tilly 1995)

22. Survey interview by author, Kyere, Côte d'Ivoire.

23. Survey interview by author, Barima, Ghana.

24. Survey interview by author, Kyere, Côte d'Ivoire.

25. These social services were formerly provided free (or at a highly subsidised cost) in both Ghan and Côte d'Ivoire, but since the implementation of structural adjustment reforms, users must pay relatively high fees to obtain access (Morris MacLean 2002).

26. Survey interview by author, Opanin, Côte d'Ivoire.

26. Survey interview by author, Opanin, Côte d'Ivoire.
27. Survey interview by author, Opanin, Côte d'Ivoire.

28. Men's focus group (tape recording), Opanin, Côte d'Ivoire, September 1999

29. Survey interview by author, Makwan, Ghana.

30. Despite contrary official rhetoric, the Ivorian decentralisation programme has been limited. The much-touted programme of 'communalisation' was moving slowly and only applied to one of the two villages.

3r. While the local organisation of political parties might have been included in an earlier section where the character of local voluntary associations was discussed, this paper examines them here to
reflect the tighter integration of parties with the state in both Côte d'Ivoire and Ghana. Although both countries had officially been multiparty political systems since the early I 990 s, the ruling party from the single-party era had continued to dominate and had, to that date, never been defeated.

32. In the past, sous-préfecture officials have experienced difficulty in designating even one official representative of each political party in order to monitor the elections at each polling station.

33. For a useful analysis of the ethno-regional politics of the Ivorian party system, see Crook (1997)

34. Frequently, village chiefs were relatively less active in Côte d'Ivoire than in Ghana, passing the majority of cases on to the justice system in the regional capital (30-60 minutes travel time away) Furthermore, there was no elected village body to regulate village problems in Côte d'Ivoire. Nor were any villagers elected to represent the village at the mayor's office or the sous-preffecture, both considered 'distant' in more than just geographical terms.

35. Voter participation is an inadequate indicator of local democratic participation and practice for
'distant in more than just geographical terms. everal reasons. First, since elections in many countries occur only once every four to five years, voter participation measures sporadic political activity and does not reflect democratic practice, voter everyday basis. Second, particularly in developing countries, elections constitute a highly formal political institution and do not reflect informal political values and pros. This comparabe locallevel data is not always available, particularly in developing countries. For this study, village-level data was only available in Ghana; in Côte d'Ivoire, the data was not collected at the village level, and participation may be slightly higher in Ghana than in Côte d'Ivoire but the difference is relatively marginal.

36. Women's focus group (tape recording), Opanin, Côte d'Ivoire, September 1999

37. Survey interview, Kyere, Côte d'Ivoire.

38. Survey interview, Opanin, Côte d'Ivoire.

39. Interview by author, Kyere, Côte d'Ivoire, 13.7.1999.

40. Peter Evans (1996) discusses the limits of locally generated social capital when there is an absence of effective linkages to the national level.

4I. Women's focus group (tape recording), Barima, Ghana, March I999.

42. Apparently, the sunk costs and barriers to entry are lower in comparison to having a case heard at the chief's court.

\section{REFERENGES}

Ayee, J. 200I. Deepening Democracy in Ghana: politics of the 2000 elections. Accra: Freedom Publications. Barth, F., ed. 1969. Ethnic Groups and Boundaries: the social organization of culture difference. Boston: Little, Brown.

Bayart, J.-F. 1993. The State in Africa: the politics of the belly. New York: Longman.

Boone, C. 1995. 'Rural interests and the making of modern African states', Journal of African Economic History $23: \mathrm{I}-36$. 
Boone, C. 2003. 'Decentralisation as political strategy in West Africa', Comparative Political Studies 36, 4 : $355^{-80}$

Bratton, M. \& N. van de Walle. 1997. Democratic Experiments in Africa. Cambridge University Press. Brown, M., ed. 200r. Nationalism and Ethnic Cionflict. Cambridge, MA: MIT Press.

Callaghy, T. M. I994. 'Civil society, democracy and economic change in Africa: a dissenting opinion', in N. Chazan, J. W. Harbeson \& D. Rothchild, eds. Civil Society and the State in Africa. Boulder, CO Lynne Rienner.

Chazan, N. 1992. 'Africa's democratic challenge', World Policy foumal 9, 2: 279-313

Collier, D. \& S. Levitsky. 1997. 'Democracy with adjectives: conceptual innovation in comparative research', World Politics 49, 3: 430-51.

Crook, R. C. I99I. 'State, society ard political institutions in Côte d'Ivoire and Ghana', in J. Manor ed. Rethinking Third World Politics. London: Longman, 213-42.

Crook, R. C. 1997. 'Winning coalitions and ethno-regional politics: the failure of the opposition in the 1990 and I995 elections in Côte d'Ivoire', African Affairs 96: 215-42.

Crook, R. C. \& J. Manor. 1998. Democracy and Decentralisation in South Asia and West Africa: participation, accountability and performance. Cambridge University Press

Deng, F. M. \& I. W. Zartman, eds. 1991. Conflict Resolution in Africa. Washington, DG: Brookings

Diamond, L. 1988. 'Introduction: roots of failure, seeds of hope', in L. Diamond, J. Linz \& S. Lipset, eds. Democracy in Developing Countries: Africa. Boulder, CO: Lynne Rienner.

Diamond, L. 1999. Developing Democracy: toward consolidation. Baltimore, MD: The Johns Hopkins University Press.

Evans, P. 1996. 'Government action, social capital and development: reviewing the evidence on synergy', World Development 24, 6: 1119-32.

Faure, Y. 1993. 'Democracy and realism: reflections on the case of Côte d'Ivoire', Africa 63, 3: $\mathrm{x}$-xx

Fine, B. 200I. Social Capital Versus Social Theory: political economy and social science at the turn of the millennium. New York: Routledge.

Fukuyama, F. 1995. Trust: the social virtues and the creation of prosperity. New York: The Free Press.

Geertz, C. 1973. 'The integrative revolution: primordial sentiments and civil politics in the new states' in Geertz, The Interpretation of Cultures: selected essays. New York: Basic Books.

Gore, C. with contributions from J. Figueiredo \& G. Rodgers. 1995. 'Introduction: markets, citizenship and social exclusion', in G. Rodgers, C. Gore \& J. Figueiredo, eds. Social Exclusion: rhetoric, reality and responses. Geneva: International Institute for Labour Studies.

Gyimah-Boadi, E. 1999. 'Ghana: the challenges of consolidating democracy', in R. Joseph, ed. State, Conflict, and Democracy in Africa. Boulder, CO: Lynne Rienner, 409-27.

Gyimah-Boadi, E. 200I. 'A peaceful turnover in Ghana', Journal of Democracy I2, 2: 103-17.

Herbst, J. 1994. 'The dilemmas of explaining political upheaval: Ghana in comparative perspective', in J. Widner, ed. Economic Change and Political Liberalization in Sub-Saharan Africa. Baltimore, MD: The Johns Hopkins University Press.

Hyden, G. 1983. Beyond Ljaama in Tanzania: underdevelopment and an uncaptured peasantry. Berkeley, CA: University of California Press.

Kasfir, N. 1998. 'The conventional notion of civil society: a critique', fournal of Commonzvealth and Comparative Politics 36,2 : $1-20$

Lake, D. A. \& D. Rothchild, eds. 1998. The International Spread of Ethnic Confict: fear, diffusion, and escalation. Princeton, NJ: Princeton University Press.

Levi, M. 1996. 'Social and unsocial capital', Politics and Society 24: 45-55.

Linz, J. \& A. Stepan. 1996. 'Toward consolidated democracies', Journal of Democracy 7, 2: 14-33.

Longman, T. 1999. 'State, civil society, and genocide in Rwanda', in R. Joseph, ed. State, Conflict, and Democracy in Africa. Boulder, CO: Lynne Rienner.

Meyer, B. 1995. "Delivered from the powers of darkness": confessions of satanic riches in Christian Ghana', Africa 65, 2: 236-55.

Middleton, J. 1983 . 'One hundred and fifty years of Christianity in a Ghanaian town', Africa $53,3: 2-19$ Migdal, J. S. 2001. State in Society: studying how states and societies transform and constitute one another. Cambridge University Press.

Morris MacLean, L. 2002. 'Constructing a social safety net in Africa: an institutionalist analysis of colonial rule and state social policies in Ghana and Côte d'Ivoire', Studies in Comparative International Development 37, 3: 64-90.

Morris MacLean, L. 2004. 'Empire of the young: the legacies of state agricultural policy on loca capitalism and social support networks in Ghana and Côte d'Ivoire', Comparative Studies in Society and History 46,3 : forthcoming.
Nugent, P. 1995. Big Men, Small Boys and Politics in Ghana: power, ideology and the burden of history, 1982-1994 London: Pinter.

Ostrom, E. 1990. Governing the Commons: the evolution of institutions for collective action. Cambridge University Press.

Owusu, M. 1970. Uses and Abuses of Political Pover: a case study of continuity and change in the politics of Ghana. Chicago: University of Chicago Press.

Putnam, R. 1993. Making Democracy Work: civic traditions in modern Italy. Princeton, NJ: Princeton University Press.

Rothchild, D. 1997. Managing Ethnic Conflict in Africa: pressures and incentives for cooperation. Washington, DG: Brookings.

Schmitter, P. C. 1992. 'Interest systems and the consolidation of democracies', in G. Marks \& L Diamond, eds. Reexamining Democracy: essays in honor of Seymour Martin Lipset. Newbury Park, CA: Sage Publications.

Schmitter, P. C. 1994. 'Democratic dangers and dilemmas', Foumal of Democracy 5, 2: 57-74

Smith, D. A. 2002. 'Consolidating democracy? The structural underpinnings of Ghana's 2000 elections', Journal of Modern African Studies $40,4: 621-50$

Stedman, S., D. Rothchild \& E. Cousens. 2002. Ending Civil Wars: the implementation of peace agreement Boulder, CO: Lynne Rienner.

Tarrow, S. 1996. 'Making social science work across time and space: a critical reflection on Rober Putnam's Making Democracy Work', American Political Science Review 9o, 2: 389-97.

Tilly, C., ed. 1995. Citizenship, Identity and Social History. New York: International Review of Social History.

Twumasi-Ankrah, K. 1994. 'Some observations on Christian Churches and worship in Ghana', International Review of Modern Sociology 24, 1: 95-108.

Varshney, A. 2002. Ethnic Conflict and Civic Life: Hindus and Muslims in India. New Haven, CT: Yale University Press.

VonDoepp, P. 2002. 'Liberal visions and actual power in grassroots civil society: local churches and women's empowerment in rural Malawi', foumal of Modern African Studies 40, 2: 273-30I.

Widner, J. 1993. 'The origins of agricultural policy in Côte d'Ivoire', Journal of Development Studies 7 25-59.

Widner, J. 1994. 'Political reform in anglophone and francophone African countries', in J. Widner, ed. Economic Change and Political Liberalization in Sub-Saharan Africa. Baltimore, MD: The Johns Hopkin Economic Change and

Woods, D. I994. 'Elites, ethnicity and "home town" associations in the Côte d'Ivoire: an historical analysis of state-society links', Africa $64,4: 465-83$.

Woods, D. I999. 'The politics of organising the countryside: rural cooperatives in Côte d'Ivoire', Joumal of Modern African Studies 37, 3: 489-506.

Woods, D. 2003. 'The tragedy of the cocoa pod: rent-seeking, land and ethnic conflict in Ivory Coast', Fournal of Modern African Studies 4I, 4: 64I-55. 